Vol. 44, N. 4 : pp. 401 - 404, December, 2001

ISSN 1516-8913 Printed in Brazil

\title{
Temperature Dependent Seed Germination of Dalbergia nigra Allem (Leguminosae)
}

\author{
Fernanda G. A. Ferraz-Grande and Massanori Takaki* \\ Departamento de Botânica - UNESP CP 199 Rio Claro - SP, Brazil
}

\begin{abstract}
The germination of endangered species Dalbergia nigra was studied and $30.5^{\circ} \mathrm{C}$ was found as optimum temperature, although the species presented a broad temperature range where germination occurs and light had no effect. The analysis of kinetics of seed germination confirmed the asynchronized germination below and above the optimum temperature. The light insensitive seed and germination also at high temperatures indicated that D. nigra could occur both in understories and gaps where the mean temperature was high.
\end{abstract}

Key words: Dalbergia nigra, endangered species, seed germination, temperature

\section{INTRODUCTION}

Dalbergia nigra commonly known as jacarandáda-Bahia, caviúna, jacarandá is an endangered species found in Atlantic Forest from Bahia to São Paulo States (Lorenzi, 1992). The species is considered as endangered specially due to its use as timber source and use of fire for agricultural pratices. It is also recommended in the reforestation programs of degraded areas (Crestana et al., 1993). In spite of its importance, the seed germination of this species was not studied. Determination of cardinal temperatures is important for the understanding of the ocurrence of this species in natural environment (Laboriau, 1983). The temperature of the soil always is different of the air and in a forest the occurrence of gap of canopy results in broad range of temperature variation during the day (Bazzaz \& Pickett, 1980). In accordance with germination behaviour the species can be classified as pioneer, secondary and climax (Budowski, 1965). Mostly the pioneer species present light sensitive seeds or germination at high temperatures and in some cases the pioneer species can germinate under both high temperature in darkness or under white light at $25^{\circ} \mathrm{C}$ (Vazquez-Yanes \& Sada, 1985).

In the present paper, we describe the temperature dependent germination behaviour of D. nigra.

\section{MATERIAL AND METHODS}

Seeds of $D$. nigra were harvested at university campus. For each germination test 20 seeds on imbibed filter paper for each of four $90 \mathrm{~mm}$ diameter Petri dishes were used throughout. Isothermic incubations were carried out in B.O.D. incubators in the range of 10 to $45^{\circ} \mathrm{C}$. Seeds with 2 $\mathrm{mm}$ long roots were considered as germinated. Day-light fluorescent light at $320 \mu \mathrm{W} . \mathrm{cm}^{-2}$ were used when indicated. The germinability was analysed according to Labouriau and Agudo (1987). Mean time of germination was obtained as

* Author for correspondence 
follows: Velocity of germination as $1 / \mathrm{t}$ where $\mathrm{t}=\Sigma$ ni.ti $/ \Sigma \mathrm{ni}$, and $\mathrm{ni}=$ number of germinated seeds at time ti; relative frequency of germination as $\mathrm{ni} / \Sigma \mathrm{ni}$. The entalpy of activation of germination $\Delta \mathrm{H}_{\mathrm{n}}{ }^{\#}\left(\mathrm{Kcal} \cdot \mathrm{mol}^{-1}\right)$ was calculated as: [R.T $(\theta-$ $\mathrm{T}) \cdot(\mathrm{Tm}+\mathrm{TM}) /(\mathrm{T}-\mathrm{Tm}) \cdot(\mathrm{TM}-\mathrm{T})]$, where $\mathrm{R}=$ universal gas constant $\left(1.987 \mathrm{Kcal}_{\mathrm{mol}}{ }^{-1}\right), \mathrm{T}=$ actual temperature $\left({ }^{\circ} \mathrm{K}\right), \quad \mathrm{TM}=$ maximum temperature of germination $\left({ }^{\circ} \mathrm{K}\right), \mathrm{Tm}=$ minimum temperature of germination $\left({ }^{\circ} \mathrm{K}\right)$ and $\theta=$ mean temperature of TM and Tm. The mean arc $\sin \sqrt{ } \%$ were analysed by Tukey test (Sokal \& Rolph, 1981). The data of velocity of germination were submitted to logistic regression according to Hsu et al. (1984).

\section{RESULTS AND DISCUSSION}

Figure 1 shows the temperature range where seeds of D. nigra germinated. Between 20 and $30^{\circ} \mathrm{C}$, seeds germinated without statistical differences indicating a broad range as optimum temperature. The germination of seeds incubated at continuous white light and continuous darkness were similar and here we are presenting only the data obtained under continuous white light. These results confirmed the broad distribution of the species in Brazil (Lorenzi, 1992).

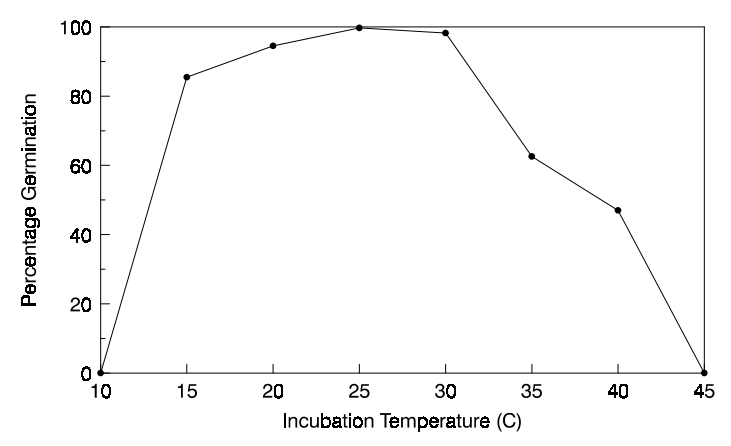

Figure 1 - Effect of incubation temperatures on percentage germination in Dalbergia nigra seeds.

The logistic regression of data of velocity of germination indicated that the highest velocity was found at $30.59^{\circ} \mathrm{C}$ with correlation coeficient of 0.999 and standard error of curve fitting of 0.00047 (Figure 2). This meant that the calculated optimum temperature was $30.59^{\circ} \mathrm{C}$ where seeds germinated fast and that almost all seeds germinated $(98 \%)$. The optimum temperature for tropical plant species was between 20 and $35^{\circ} \mathrm{C}$
(Brasil, 1992) although Vazquez-Yanes and Orozco-Segovia (1974) reported near $40^{\circ} \mathrm{C}$ as optimum temperature for Ochroma lagopus.

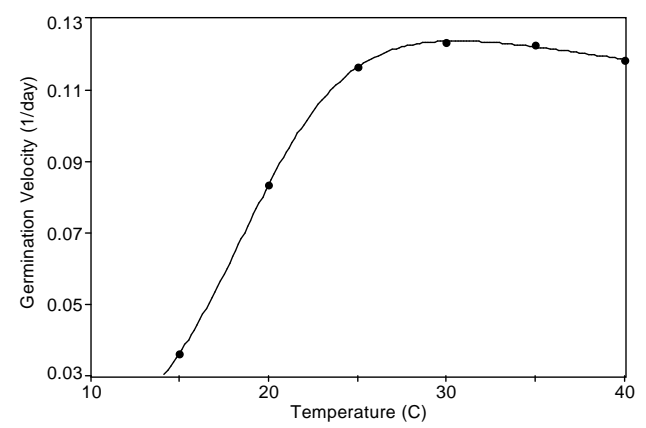

Figure 2 - Logistic regression of data of velocity of seed germination in Dalbergia nigra at different incubation temperatures.

Figure 3 shows the relative frequency of germination and it was observed that below and above optimum temperature the distribution of germination was spread in time but at optimum temperature there was a synchronization of germination with tendency of unimodal distribution of germination frequency. For crops the synchronization of seed germination is important for homogeneous growth of plants and some pratices are recommended such as priming (Heydecker \& Coolbear, 1977) but in the nature the asynchronised seed germination is more important than synchronised germination for the maintainance of delayed-transient seed bank in the soil (Garwood, 1989) and when conditions are adequate, the germination process is induced for the establishment of successional events.

The enthalpy of activation of germination was calculated and according to Laboriau and Agudo (1987), between $+12 \mathrm{Kcal}$ and $-12 \mathrm{Kcal}$ the velocity of germination is dependent on the oxygen and water difusion processes (figure 4). This meant that below $22.5(+12 \mathrm{Kcal})$ and above $31.6^{\circ} \mathrm{C}(-$ $12 \mathrm{Kcal})$ the germination process was dependent on other processes such as phase transition at low temperatures and thermodenaturation of protein at high temperatures (Taylorson and Hendricks, 1972). 

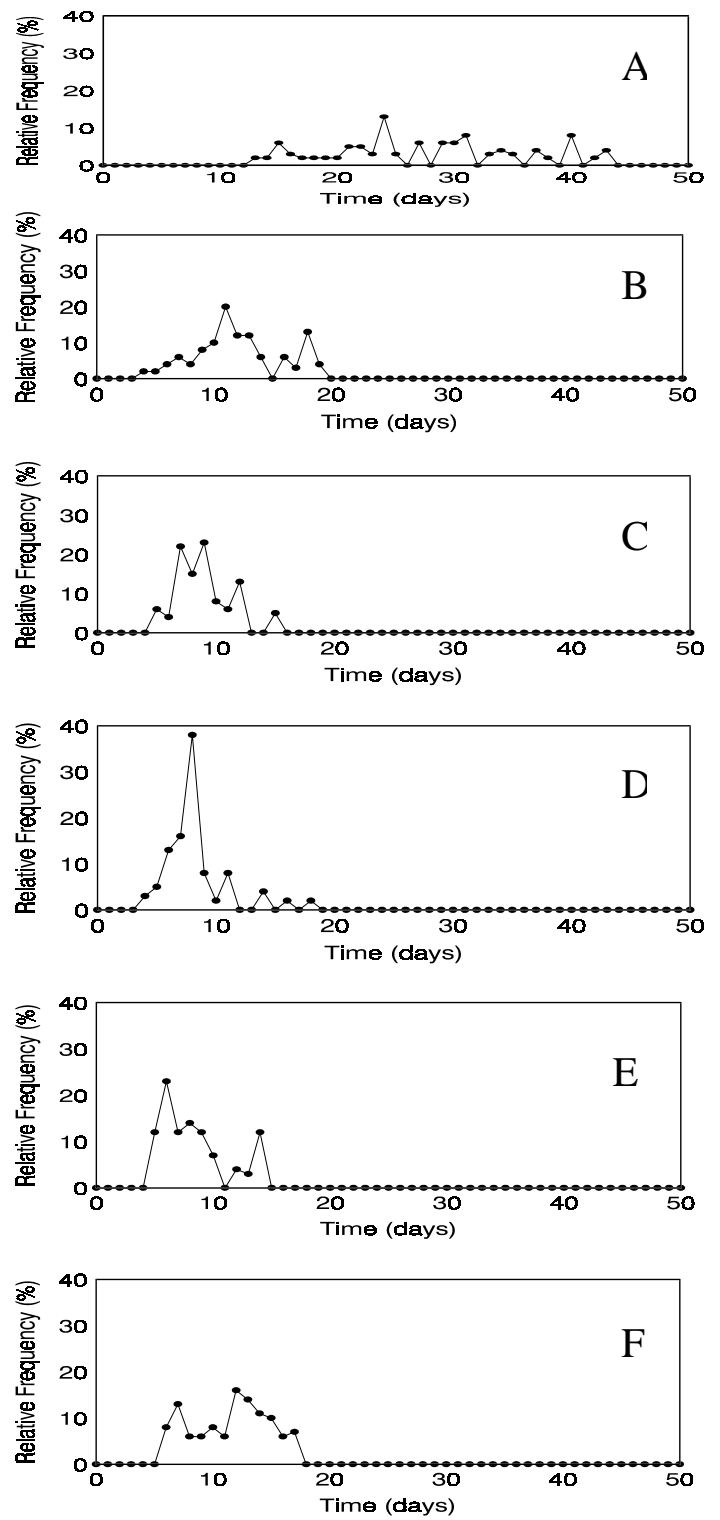

Figure 3 - Relative frequency of seed germination in $D$. nigra. $\mathrm{A}=15^{\circ} \mathrm{C}, \mathrm{B}=20^{\circ} \mathrm{C}, \mathrm{C}=25^{\circ} \mathrm{C}, \mathrm{D}=30^{\circ} \mathrm{C}, \mathrm{E}=35^{\circ} \mathrm{C}$ e $\mathrm{F}=40^{\circ} \mathrm{C}$.

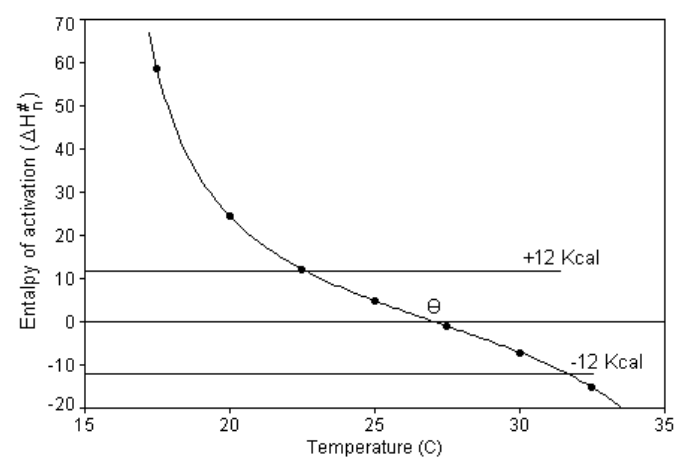

Figure 4 - Enthalpy of activation of seed germination in D. nigra, where $\theta=$ harmonic mean temperature between maximum and minimum temperature of germination.
Our results indicated that the species was light insensitive and only the temperature was responsible for the control of germination. Because the seeds of D. nigra could also germinate at high temperature, although the kinectics of seed germination indicated that the process was limited, probably by denaturation of proteins the possibility was that the species occurs in both understories and gaps where the mean temperature usually was high (Van Der Meer et al., 1999)

\section{RESUMO}

A germinação de sementes de Dalbergia nigra Allem, comumente conhecida como jacarandá-daBahia, caviúna, jacarandá, uma espécie em extinção, foi estudada e determinamos a temperatura ótima de $30,5^{\circ} \mathrm{C}$. A espécie apresenta uma ampla faixa de temperatura onde a germinação ocorre e a luz branca não influenciou o processo. A análise da cinética da germinação de sementes confirma a germinação não sincronizada acima e abaixo da temperatura ótima de germinação. A semente insensível à luz e a germinação também em altas temperaturas indicam que $D$. nigra pode ocorrer tanto na sombra da vegetação bem como em clareiras.

\section{ACKNOWLEDGEMENTS}

F.G.A.F.G had CAPES studentship and M.T. was CNPq Research fellow. This work was aided by grants from FAPESP, CNPq and FUNDUNESP.

\section{REFERENCES}

Bazzaz, F. A. and Pickett, S. T. A. (1980), Physiological ecology of tropical sucession: a comparative review. Annual Review of Ecology and Systematics, 11, 287-310.

Brasil. Ministério da Agricultura e Reforma Agrária. (1992), Regras para Análise de Sementes. Brasília: SNDA/ DNDU/ CLA, 365p.

Budowski, G. (1965), Distribution of tropical American rain forest species in the light successional processes. Turrialba, 15, 40-42.

Crestana, M. S. M.; Toledo Filho, D. V. and Campos, J. B. (1993), Florestas. Sistemas de recuperação com essências nativas. CATI, 60p. 
Garwood, N. C. (1989), Tropical soil seed banks: a review. In: Leck, M. A; Parker, V. T. and Simpson, R. L. (ed) Ecology of soil seed banks, Academic Press Inc, 149-209.

Heydecker, W. and Coolbear, P. (1977), Seed treatments for improved performance-survey and attempted prognosis. Seed Science and Technology, 5, 353-425.

Hsu, F. H.; Nelson, C. J. and Chow, W. S. (1984), A mathematical model to utilize the logistic function in germination and seedling growth. Journal of Experimental Botany, 35, 1629-1640.

Laboriau, L. G. and Agudo, M. (1987), On the physiology of seed germination in Salvia hispanica L. I. Temperature Effects. Anais da Academia Brasileira de Ciências, 59, 37-56.

Lorenzi, H. (1992), Árvores Brasileiras: manual de identificação de plantas arbóreas nativas do Brasil. São Paulo : Ed. Plantarum, p236.
Sokal, R. R. and Rolph, F. J. (1981), Biometry, 2nd Ed. W. H. Freeman and Co., San Francisco, 419p. Taylorson, R. B. and Hendricks, S. B. (1972), Interactions of light and temperature shift on seed germination. Plant Physiology, 49, 127-130.

Van Der Meer,; Dignan, P. D. and Saveneh, A. G. (1999), Effect of gap size on seedling establishment, growth and survival at three years in mountain ash (Eucalyptus regnans F. Muell.) forest in Victoria, Australia. Forest Ecology and Management, 117, 33-42.

Vazquez-Yanes, C. and Orozco-Segovia, A. (1974), Seed germination of Ochroma lagopus. Turrialba, 24, 1276-1279.

Vazquez-Yanes, C. and Sada, S. G. (1985), Caracterizacion de los grupos ecologicos de arboles de la selva humeda. In Gomez-Pompa, A. \& Amo, S. (ed.) Investigaciones sobre la regeneracion de selvas altas en Veracruz, Mexico Ed. Alhambra Mexicana, 6-78. 